\title{
再生石膏のアスファルト混合物 フィラー材への適用性
}

\author{
古賀千佳嗣 ${ }^{1} \cdot$ 佐藤研一 ${ }^{2} \cdot$ 藤川拓朗 $^{2} \cdot$ 吉中保 $^{3} \cdot$ 大城謙次 $^{4}$ \\ 1 正会員 修士（工） 福岡大学 工学部 （广814-0180 福岡市城南区七隈 8-19-1） \\ E-mail : chikashi@fukuoka-u.ac.jp \\ 2 正会員 博士（工） 福岡大学 工学部 （=814-0180 福岡市城南区七隈 8-19-1） \\ 3 正会員 博士 (工) 株式会社NIPPO 九州支店試験所 (†811-2101 福岡県糟屋郡宇美町大字宇美安楽寺3381-9) \\ 4 正会員 株式会社 NIPPO 九州支店試験所（广811-2101 福岡県糟屋郡宇美町大字宇美安楽寺 3381-9）
}

\begin{abstract}
本研究では，廃石膏ボードを紙片類と破砕分離した再生二水石膏と，さらに再生二水石膏を焼成処理するこ とによって得られる再生半水石膏に着目し，これらの再生石膏をアスファルト混合物フィラー材に代替するリ サイクル方法の検討を行った. その結果, 再生石膏をアスファルト混合物に混合すると, 空隙率の増加, 耐水 性の低下がみられる一方, 残留安定度の増加がみられた。フィラー材に対しての代替率は，密粒度アスファル 卜混合物では再生二水石膏で 40\%程度, 再生半水石膏 75\%程度, ポーラスアスファルト混合物においては $100 \%$ 代替が可能であることが明らかとなった。 また，周辺環境へ及ぼす影響について，タンクリーチング試験から 検討した結果，今回のアスファルト混合物からの重金属等の溶出はみられないことが示された.
\end{abstract}

Key Words : Recycled gypsum, Filler materials, Asphalt mixture, Reproduction gypsum mixture rate

\section{1. はじめに}

石膏ボードとは，石膏を主成分とした素材を板状にし て特殊な用紙で包んだ建築材料である. 非常に丈夫であ り，断熱・遮音性が高い性質を持っている，そのため， 用途に合わせて防火・防水・而震・防湿などその種類は 多種に渡り，広く建材として使用されている。この石膏 ボードの廃棄量は，年間約 190 万 $\mathrm{t}$ とれれ，今後も廃棄 量の増大が懸念されている ${ }^{1)}$. また, 廃石膏ボード (写 真-1）は従来, 安定型処分場への処分が義務付けられて いた. しかし，安定型処分場内における硫酸塩還元菌に よる硫化水素の発生が顕在化した，そこで現在では，法 律の改正 (環境省: 環廃産発 060601001 号通知)に伴い, 産業廃棄物してボード紙と石膏に中間処理した後に管理 型最終処分場への埋め立て処分が義務付けられている ${ }^{2)}$. 管理型処分は安定型処分に比べ処分費用が高く，新しい 処分場の建設も困難であるため, 廃石膏を利用する新し いリサイクル技術の開発が急務とされている.

廃石膏ボードは，一般に建築現場から中間処理施設場 に運び込まれ，まず石膏と紙片類に破砕分離される.こ こで回収される石膏を再生二水石膏と呼び，さらに再生
二水石膏に $110 \sim 130^{\circ} \mathrm{Cで}$ 焼成処理を加えたものを再生 半水石膏としている.

一方，アスファルト混合物に廃棄物をリサイクル材と して配合した研究は，これまでに数多く行われてきた. これらの中には，実際に施工が可能とされ実用化されて いるものや, 火力発電所から発生するフライアッシュや 一般廃棄物溶融スラグなどをアスファルト混合物の骨材 の一部に代替材として使用する研究事例もある ${ }^{3)-5)}$.

そこで本研究では，廃石膏ボードから生成される再生 二水石膏及びIH（電磁誘導）焼成方式（写真-2）で焼成 された再生半水石膏に着目し，同様の性質を持つアスフ アルト混合物フィラー材の代替材としての適用性につい て検討を行った. 特に石膏の混入率を変化させた時の舗 装材料としての性能と環境へ与える影響について検討を 行った結果について報告する。

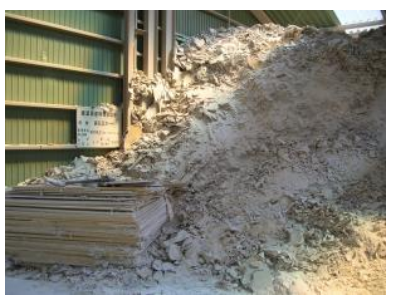

写真-1 廃石膏ボード

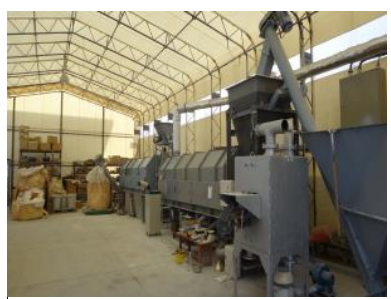

写真-2 IH 焼成方式 


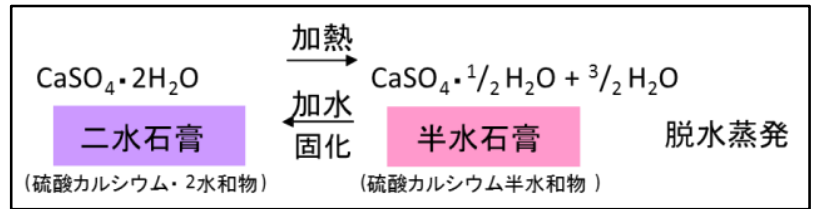

図-1 石膏の加水及び燒成に伴う関係

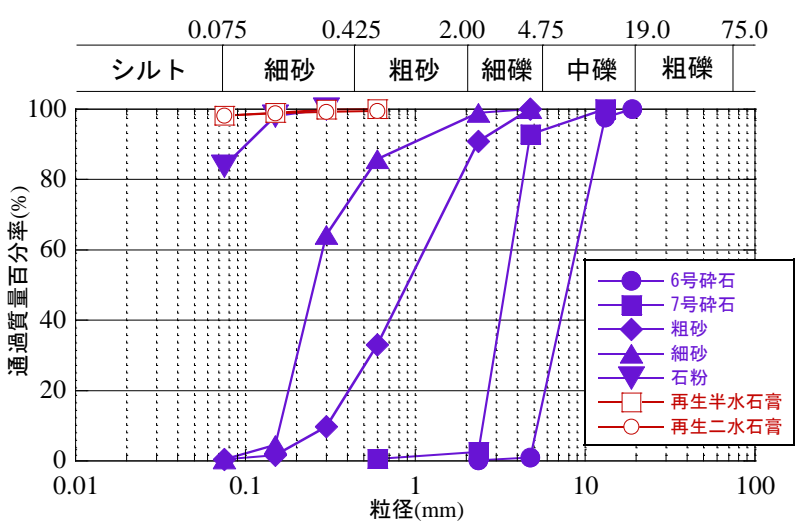

図-2＼cjkstart骨材の粒径加積曲線

表-1＼cjkstart骨材の物理特性

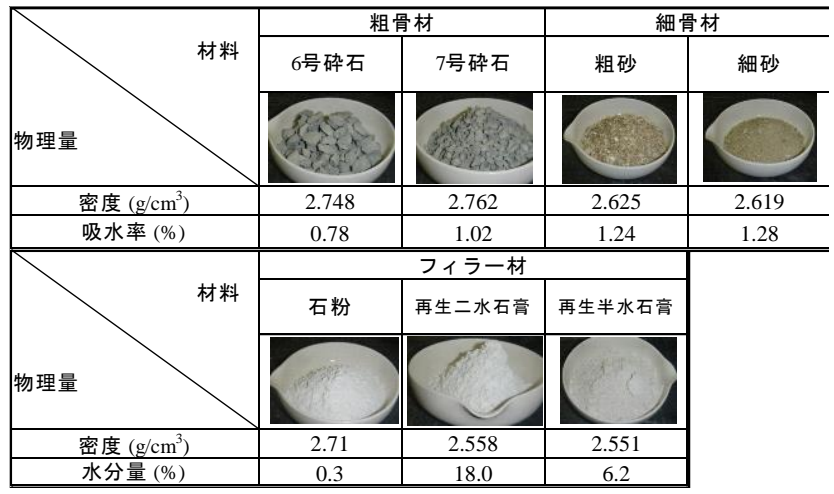

\section{2. 実験概要}

\section{（1）実験に用いた試料}

本研究では，アスファルト混合物の骨材として 6 号砕 石， 7 号砕石，粗砂，細砂を使用した. また，フィラー 材には，石粉，再生二水石膏，IH 焼成方式で焼成された 再生半水石膏を使用した. 図-1 に石膏の加水及び焼成に 伴う関係図を示す. アスファルトとしてストレートアス ファルト 60-80 およびポリマー改質アスファルト $\mathrm{H}$ 型を 用いて，密粒度アスファルト混合物(13)（略記 : 密粒度 As 混合物) およびポーラスアスファルト混合物(13)（略 記 : ポーラス As 混合物）供試体を作製した。石膏にお いては常温で混合時に投入した. 図-2に骨材の粒径加積 曲線を示す. 図-2 より再生二水石膏と再生半水石膏は同
表-2 再生半水石膏の溶出特性

\begin{tabular}{|c|c|c|c|c|c|c|}
\hline \hline & $\mathrm{F}(\mathrm{mg} / \mathrm{l})$ & $\mathrm{SO}_{4}{ }^{2-}(\mathrm{mg} / \mathrm{l})$ & $\mathrm{B}(\mathrm{mg} / \mathrm{l})$ & $\mathrm{Cr}^{6+}(\mathrm{mg} / \mathrm{l})$ & $\mathrm{Cd}(\mathrm{mg} / \mathrm{l})$ & $\mathrm{Pb}(\mathrm{mg} / \mathrm{l})$ \\
\hline 再生半水石唷 & 5.94 & 2432.15 & 0.07 & $\mathrm{~N} . \mathrm{D}$ & $\mathrm{N} . \mathrm{D}$ & $\mathrm{N} . \mathrm{D}$ \\
\hline 土堙環境基準値 & 0.80 & - & 1.00 & 0.05 & 0.01 & 0.01 \\
\hline
\end{tabular}

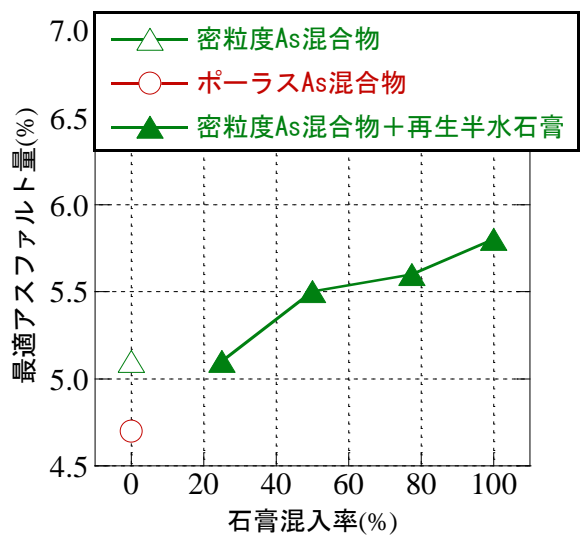

図-3 石膏混入率と最適アスファルト量

様の粒度分布を示し，石粉よりも細粒分が多い材質とな っている. 表-1 に骨材の物理特性を示す. 表-1 より再生 石膏は石粉に比べ水分量が多く，特に再生二水石膏にお いては廃石膏を破砕し, 機械的に振ったため $18 \%$ に至 る. また，外観において再生二水石膏は微量の紙屃を含 んでいる. これは中間処理工程において機械選択の際に 含まれるものと考えられる. それに比べ再生半水石膏は 焼成段階により紙屑等が取り除かれ，水分量が低下し， 石粉に近い状態となっている. 表-2 に再生半水石膏の溶 出特性を示す。フッ素においては単体で土壌環境基準の $0.8 \mathrm{mg} / \mathrm{l}$ 以上の $5.94 \mathrm{mg} / \mathrm{l}$ 值を示していることがわかる.

\section{(2) 配合設計}

配合設計にあたり, 密粒度 As 混合物内のフィラー材 における石膏混入率を 0，25，50，75，100\%の計 5 種類 とし，アスファルト量を 4.5～6.0\%に変化させ配合試験 を行い，最適アスファルト量を算出した．ここで，石膏 混入率（以降のすべての図も同様）とは，フィラー材中 の石膏混入割合である. 図-3に再生石膏混入率と最適ア スファルト量の関係を示す. 結果より再生半水石膏の増 加に伴い最適アスファルト量が増加していることがわか る. これは，焼成された再生半水石膏は水分を失い吸水 性が高いことが原因と考えられる. 一般的にアスファル 卜混合物の材料特性は, 最適アスファルト量を用いて行 う。しかし, 今回は再生石膏混入率の変化に伴うアスフ アルト混合物の性状変化を知るため, 石膏混入率 $0 \%$ の 時における最適アスファルト量(密粒度As混合物: $5.1 \%$, ポーラス As 混合物 : $4.7 \%$ ) を基準として検討を行った. 
表-3 再生石膏の種類の違いによる実験条件

\begin{tabular}{c|c|c|c|c|c}
\hline \multirow{2}{*}{ 混合物種 } & \multirow{2}{*}{ 再生石膏種 } & \multicolumn{2}{|c|}{$\begin{array}{c}\text { フイラ一内訳 } \\
\text { (対フィラー\% }\end{array}$} & \multirow{2}{*}{$\begin{array}{c}\text { As量 } \\
\text { (一定) }\end{array}$} & 試験内容 \\
\cline { 3 - 4 } & & 石粉 & 石膏 & & \\
\hline & & 100 & 0 & & \\
密粒度 & 再生二水石膏 & 90 & 10 & & 標準MT \\
アスファルト & 再生半水石膏(IH焼成) & 80 & 20 & \multirow{2}{*}{$5.1 \%$} & 水浸MT \\
混合物(13) & & 70 & 30 & & WT \\
& & 60 & 40 & & \\
& & 50 & 50 & & \\
\hline
\end{tabular}

表-4 アスファルト混合物の違いによる実験条件

\begin{tabular}{|c|c|c|c|c|c|}
\hline \multirow{2}{*}{ 混合物種 } & \multirow{2}{*}{ 再生石膏種 } & \multicolumn{2}{|c|}{\begin{tabular}{|c} 
フィラー材 \\
(対フィラー\%)
\end{tabular}} & \multirow{2}{*}{ As量 $(\%)$} & \multirow{2}{*}{ 試験内容 } \\
\hline & & 石粉 & 石膏 & & \\
\hline $\begin{array}{c}\text { 密粒度 } \\
\text { アスファルト } \\
\text { 混合物(13) }\end{array}$ & \multirow{2}{*}{$\begin{array}{l}\text { 再生半水石膏 } \\
\text { (IH焼成方式) }\end{array}$} & $\begin{array}{l}100 \\
75\end{array}$ & $\begin{array}{c}0 \\
25\end{array}$ & $5.1 \%$ & \multirow{2}{*}{$\begin{array}{l}\text { 標準MT } \\
\text { 水浸MT }\end{array}$} \\
\hline $\begin{array}{l}\text { ポーラス } \\
\text { アスファルト } \\
\text { 混合物(13) }\end{array}$ & & $\begin{array}{c}50 \\
25 \\
0\end{array}$ & $\begin{array}{c}50 \\
75 \\
100\end{array}$ & $4.7 \%$ & \\
\hline
\end{tabular}

表-5 溶出特性の実験条件

\begin{tabular}{|c|c|c|c|c|c|c|}
\hline \multirow{2}{*}{ 混合物種 } & \multirow{2}{*}{ フィラ一材 } & \multirow{2}{*}{$\begin{array}{c}\text { 供試体の } \\
\text { 状態 }\end{array}$} & \multirow{2}{*}{ As量(\%) } & \multicolumn{2}{|c|}{ 配合比 $(\%)$} & \multirow{2}{*}{ 試験内容 } \\
\hline & & & & 石粉 & 石膏 & \\
\hline \multirow{3}{*}{$\begin{array}{c}\text { 密粒度 } \\
\text { アスファルト } \\
\text { 混合物 (13) }\end{array}$} & \multirow{3}{*}{$\begin{array}{l}\text { 再生半水石膏 } \\
\text { (IH焼成方式) }\end{array}$} & \multirow{3}{*}{$\begin{array}{c}\text { MT試験 } \\
\text { 供試体 }\end{array}$} & \multirow{3}{*}{5.1} & 100 & 0 & \multirow{3}{*}{$\begin{array}{c}\text { タンク } \\
\text { リーチング }\end{array}$} \\
\hline & & & & 50 & 50 & \\
\hline & & & & 0 & 100 & \\
\hline
\end{tabular}

\section{（3）再生石膏の種類の違いによる影響}

実験条件を表-3に示寸. アスファルト混合物には密粒 度 As 混合物を用いた. 配合設計より最適アスファルト 量である 5.1\%を一定のアスファルト量として供試体を 作製した. アスファルト混合物フィラー中の石膏混入率 は 0，10，20，30，40，50\%と設定した. 試験はアスフ アルト混合物の試験において最も一般的とされている標 準マーシャル試験（略記 : 標準 MT), 水浸マーシャル試 験 (略記: 水浸 MT)，ホイールトラッキング試験 (略記 : WT）の 3 種類の試験を行い, 石膏混合によるアスファ ルト混合物の材料特性が及ぼす影響について検討を行っ た.

\section{（4）アスファルト混合物の違いによる影響}

密粒度 As 混合物は，（3）と同条件にてストレートアス ファルト 60-80を用いて 5.1\%，ポーラス As 混合物には ポリマー改質アスファルト $\mathrm{H}$ 型を用いて $4.7 \%$ で供試体 を作製した。実験では，再生半水石膏のみに着目し，表 -4 に示寸実験条件に従って石膏混入率を $0,25,50,75$, $100 \%$ と設定した. 各混合物の供試体について, 標準マー シャル試験および水浸マーシャル試験を行った。 また, 密粒度 As 混合物のみホイールトラッキング試験を，ポ ーラス As 混合物には骨材飛散抵抗性を調べるためカン タブロ試験を行った. これにより，アスファルト混合物 の違いによる再生石膏の影響について検討を行った.

\section{（5）溶出特性}

再生石膏は重金属を含み, 表-2 に示寸ように特にフッ 素においては単体で土懔環境基準の $0.8 \mathrm{mg} / 1$ 以上の $5.94 \mathrm{mg} / 1$ 值を示寸.このため環境周辺への影響を考慮す る必要がある. 表-5に実験条件を示す.アスファルト混 合物には密粒度 As 混合物を用いて石亳混入率を対フィ ラーで 0，50，100\%と設定し，標準マーシャル試験供 試体と同様の手法によって作製した. 今回は劣化による 骨材粉砕時の溶出においては考慮せず，供試体そのもの の溶出特性に着目し, タンクリーチング試験を行った. $\mathrm{pH} 5.8 \sim 6.3$ に設定し固液比 $1: 10$, 試料の乾燥重量 10 倍 体積の溶媒水に水浸させ, $20^{\circ} \mathrm{C} の$ 恒温室内に 28 日間養生 を行い，それらの検体について JIS K0102の 65.2 に従っ て濃度測定を行った。

\section{3. 結果及び考察}

\section{（1）再生石膏の種類の違いによる影響}

図-4に空隙率と石亳混入率の関係を示寸. 空隙率は石 膏混入率の増加に伴い, 再生二水石膏においては増加傾 向を示したが，石膏混入率 50\%で 5.3\% と基準值である 6.0\%を満足していることがわかる. しかし，これ以上の 再生二水石膏を混入すると基淮值を超える可能性がある 結果となっている. これに対し, 再生半水石膏において は石膏混入率の増加に伴って緩やかな上昇傾向を示して いるものの, 石膏混入率 50\%で $3.5 \%$ と石粉の夕の場合と ほとんど変わらない值を示した．このように再生二水石 亳と再生半水石膏で空隙率の違いがあらわれたのは, 表 -1 に示した再生石膏に含まれる水分が, 加熱に伴う気化 もしくは他の材料へ移行し，混合物内に空隙ができたた めと考えられる.

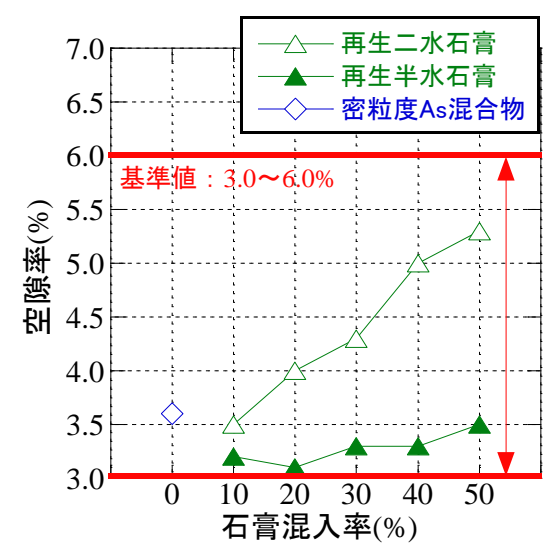

図-4 空隙率と石亳混入率の関係 
図-5にマーシャル安定度と石膏混入率の関係を示す． 安定度は石膏混入率の増加に伴いどちらの再生石膏も緩 やかな低下傾向を示した．しかしながら，全ての石膏混 入率において基淮值である $4.9 \mathrm{kN}$ を満足しており安定度 に関して再生石亳の利用に問題ないといえる。 また, 緩 やかな低下傾向は，供試体締固まり不足が結果としてあ らわれたものである.これは材料混合時に石膏を最後に 投入するため，石膏内の水分によって材料が団粒化しや すいこと，加熱混合時にアスファルトが気泡状となり， 加熱混合後の温度の低下によると考えられる.

図-6 に残留安定度と石膏混入率の関係を示寸. 再生二 水石膏においては石膏混入率が $30 \%$ こえると残留安定 度が急激な低下傾向を示した。石膏混入率 50\%で $71.0 \%$ と基準值である 75\%を下回った。 これに対し，再生半水 石膏においては石膏混入率 10\%で $85.2 \%$ ，石膏混入率

50\%で 88\%とあまり変化せず十分に利用可能な挙動を示 した. これは，再生半水石高は再生二水石高に比べ水分 少なく，アスファルトを吸収しやすく，アスファルト皮 膜が十分に保てている事に原因があると考えられる。こ のように再生半水石膏であれば耐水性が保持され，石膏 混入率が 50\%までは基準值を満足することが示唆された.

図-7 に動的安定度と石膏混入率の関係を示寸. 動的安 定度は石亳混入率の増加に伴い再生二水石膏においては ほぼ変化しない傾向を示し，再生半水石亳においては上 昇傾向を示した。また，全ての石膏混入率において密粒 度 As 混合物よりも大きく, 基淮值である 500 回 $/ \mathrm{mm}$ を 満足している.これは，再生石膏がアスファルトを吸収 する能力により結合力が向上したためと考えられる.

以上より，再生二水石膏においては石膏混入率 40\%程 度が代替の限界であるが，再生半水石膏においては $50 \%$ 以上代替出来る可能性がある. このことから，再生半水 石膏の方が再生二水石膏に比べてアスファルト混合物に 適していると言える. しかし，再生二水石稁は初期の水 分量が多く, 紙屑が微小に含まれていることで，これら の増減率を大きくしていると考えられる.

\section{（2）アスファルト混合物の種類の影響}

3. (1)より再生半水石膏の方がアスファルト混合物に 適していることから，フィラー材には再生半水石膏を用 いて検討を行っている. 図-8 に空隙率と石膏混入率の関 係を示寸．密粒度 As 混合物では石膏混入率の増加に伴 い空隙率は上昇する傾向を示しているのに対し，ポーラ ス As 混合物では石亳混入率と関係なく空隙率は $21 \%$ 前 後の一定值を示した. 密粒度 As 混合物の傾向の原因と しては前述のように，再生半水石膏がアスファルトを吸 収し間隙が充填できなかった事や水分による混合温度が 低下した事による混合効率の低下等が挙げられる.一方, ポーラス As 混合物は，アスファルトの違いに起因する

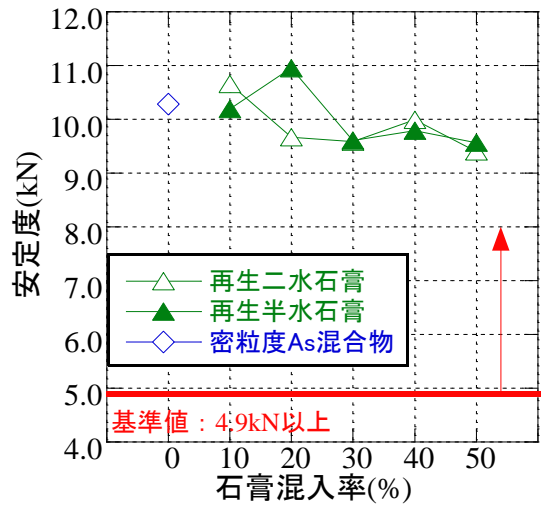

図-5＼cjkstart安定度と石膏混入率の関係

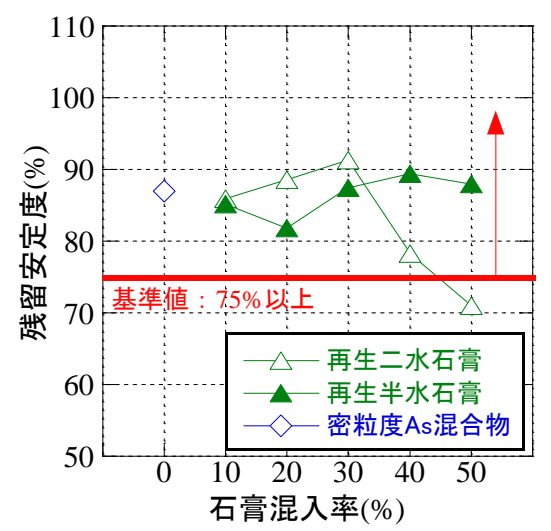

図-6 残留安定度と石膏混入率の関係

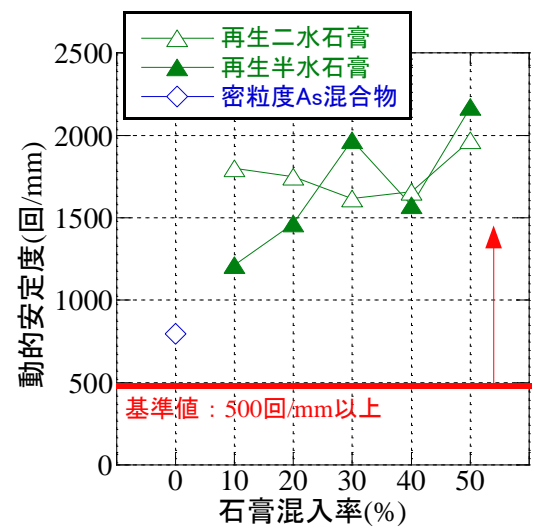

図-7 動的安定度と石膏混入率の関係

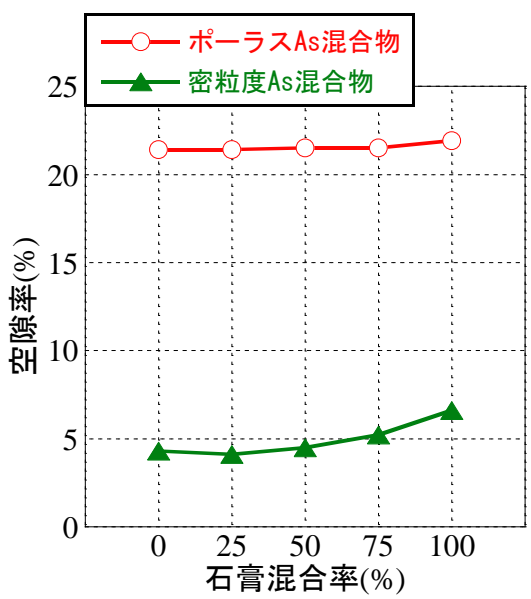

図-8 空隙率と石膏混入率の関係 
と考えられ，今回用いたポリマー改質アスファルトが密 粒度As 混合物のストレートアスファルト 60-80に比べて 高い粘性を持っていた事から，石膏添加による性状変化 が鈍化したものと考えられる.

図-9 に安定度と石膏混入率の関係を示す. 安定度は密 粒度 As 混合物およびポーラス As 混合物共に石膏混入率 の増加に伴って僅かな増加傾向を示し，全ての石膏混入 率において基準值を満たす結果が得られた。この増加傾 向は，石粉に対し石膏がアスファルトを吸収する能力に 長けており，石膏の混合比が増えていくことで同時に吸 収力が向上し，強度が増したためであると考えている. また，全ての石膏混入率において基準值である $4.9 \mathrm{kN}$ を 満足しており安定度に関してのみであれば再生半水石膏 を使用する事は石膏混入率 $100 \%$ あっあても問題ないと 言える.

図-10に残留安定度と石膏混入率の関係を示す，石膏 混入率の増加に伴い, 急激な低下傾向を示した密粒度 As 混合物に比べて，ポーラス As 混合物では石膏混入率が 増加しても残留安定度はあまり変化せずに全ての配合で 基準值を満たした。 この事から，IH 焼成方式によって焼 成された再生半水石膏は石膏混入率 $75 \%$ を超えると，耐 水性において基準を満足できない事がわかった。 これは 再生半水石膏の増加に伴って石膏自体の水分の吸収量が 増加することにより，安定度が低下したためと考えられ る.また，ポーラス As 混合物の傾向の原因として，ポ リマー改質アスファルトの使用によって粘性が向上し， 水の影響を受けにくくなっているためと考えられる.さ らに，使用した骨材表面積より算出したアスファルトの

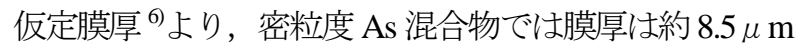
であるのに対し, ポーラス As 混合物の膜厚は約 $13.3 \mu \mathrm{m}$ と厚く，これによって温水が浸透しにくくなったためで あると言える。

図-11に密粒度As 混合物における動的安定度と石膏混 入率の関係を示す．動的安定度は石膏混入率の増加に伴 い，平均的に高い值を維持したまま，緩やかな上昇傾向 を示した．また，全ての石膏混入率において基準值であ る 500 回/mm を満足した。これは前述のように，石膏が アスファルトを吸収する能力により結合力が向上した事 が原因と考えられる.この事から，実際，最適アスファ ルトで行う場合，アスファルト量が増加するため，コス トの増加が懸念される．しかし，石膏投入による動的安 定度の増加も期待できる。

図-12にポーラスAs混合物のカンタブロ損失率と石膏 混入率の関係を示す. 石膏混入率の増加に伴い, カンタ ブロ損失率は石膏混入率 0 75\%では多少のばらつきは あるものの全体としてはあまり変化しない值を示し，石 膏混入率 $100 \%$ では，わずかに増加する傾向を示した。 これは，石膏混合によって安定度が増加した反面，骨材

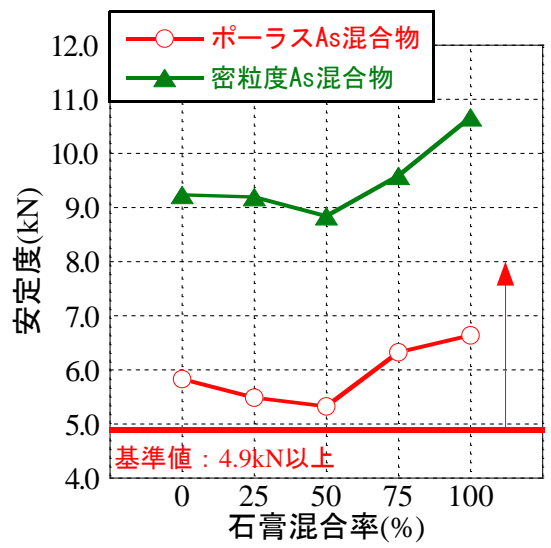

図-9 安定度と石膏混入率の関係

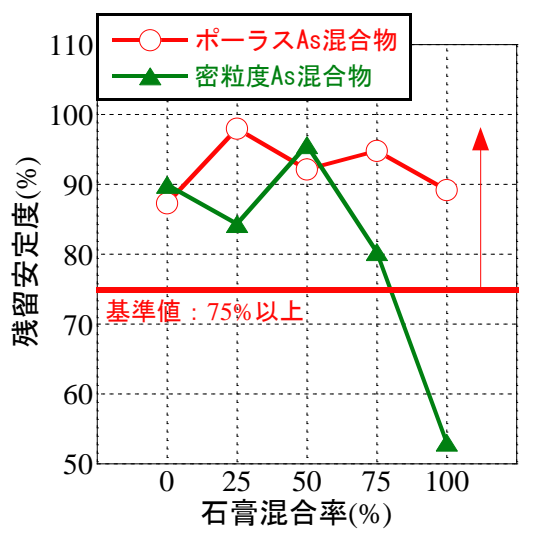

図-10 残留安定度と石膏混入率の関係

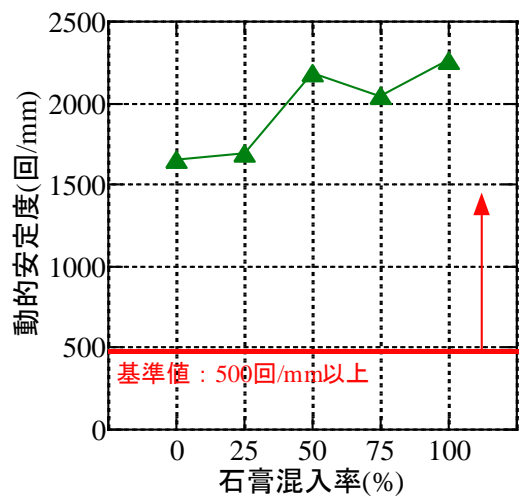

図-11 動的安定度と石膏混入率の関係 (密粒度アスファルト混合物)

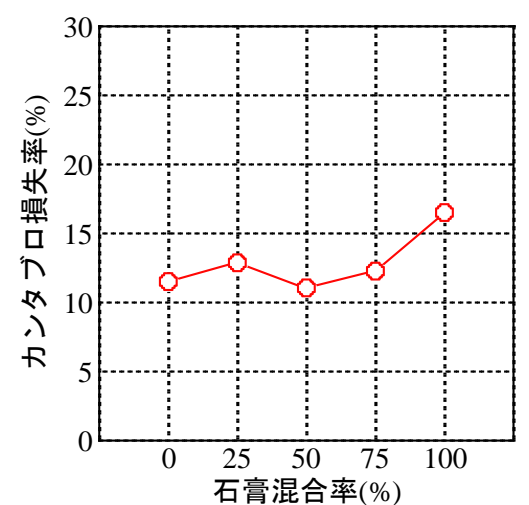

図-12 カンタブロ損失率と石膏混入率の関係 (ポーラスアスファルト混合物) 
飛散抵抗性が低下したことを示している。このことか ら，ポーラス As 混合物に石膏を用いる場合には，混合 比の設定に注意する必要がある。

以上より, IH 焼成方式で焼成された再生半水石膏をつ イラー材に代替する場合，フィラー材の代替材として 75\%程度が限界であることが示された．また，ポーラス As 混合物に再生半水石膏を代替使用寸ることは十分可 能であることが示された．密粒度 As 混合物において課 題点としていた空隙の増加や石膏自体の水分の吸収等の 影響はポーラス As 混合物にはほとんど見られず，利用 可能な挙動を示した．ただし，飛散抵抗性が低下する観 点から代替する際には交差点等のねじり荷重がよくかか る場合等には注意が必要である.

\section{（3）アスファルト混合物からの溶出特性}

今回，密粒度 As 混合物を用いたタンクリーチング試 験の結果, 有害物質の溶出は確認されなかった. これは, アスファルトが骨材を完全に皮膜した事に起因すると考 えられる.しかし，今後はアスファルトの劣化により粉 砕し比表面積が大きくなると溶出の可能があるため, 更 なる検討が必要である.

\section{4. 結論}

1) 密粒度 As 混合物フィラー材に再生石膏を代替した場 合, 再生二水石膏では 40\%程度, 再生半水石膏では 75\% 程度が代替の限界である。

2) 再生二水石膏は多くの水分と紙屑を含むため, 空隙率 を高め, 紙屑がアスファルトを吸収し, 安定度を低下さ
せる. そのため, アスファルト混合物フィラー材にはあ まり適していないと考えられる。

3）アスファルト混合物に再生半水石膏を代替した際, 再 生石膏の増加に伴って空隙率の増加, 而水性の減少, 而 流動性の向上等の影響が発生する.この原因として, 再 生石膏のアスファルト吸収作用, 石膏自体の水分吸収作 用が原因と考えられる.

4) ポーラス As 混合物に再生半水石膏を代替使用するこ とは十分可能である. ただし, 飛散抵抗性の低下が生じ るため交差点等のねじり荷重がよくかかる場合につい ては更なる検討が必要である。

5) タンクリーチング試験を用いた再生石膏を用いたア スファルト混合物からの溶出試験から有害物質の溶出 は確認されなかった. しかし，今後はアスファルトの劣 化の可能性を踏まえ検討する必要がある.

\section{参考文献}

1) 廃石膏ボードの対応策について, http://www.gypsumboard-a.or.jp/countermeasure.pdf

2) 環境省廃棄物リサイクル対策部: 平成 20 年度廃石膏ボード の再資源化促進方策検討業務調査報告書

3) 大矢ら: 安定化処理後下水污泥焼却灰入りアスファルト混合 物，日本下水道協会,再生と利用,2011,Vol35,No131,D-2

4) 大河内ら:溶融スラグ入りポーラスアスファルト混合物の検 討，土木学会第64 回年次学術講演会,5-021

5) 柴田ら: 石炭灰のアスファルトフィラー材への適用検討 中部電力, 柴田ら, 技術開発ニュース,No131/2008-7

6) 社団法人日本道路協会:舗装施工便覧,2006,p121

\title{
APPLICABILITY TO ASPHALT MIXTURE FILLER MATERIALS OF THE REPRODUCTION GYPSUM
}

\author{
Chikashi KOGA,Kenichi SATO, Takuro FUJIKAWA, \\ Tamotsu YOSHINAKA and Kenji OOGI
}

This study deals with recycling of gypsum as well as recycling of hemihydrate gypsum generated from burning of waste plasterboards. Correspondingly, this study is devoted to examine the effect of gypsum content and the surrounding environment on the mechanical characteristics of asphalt mixtures and to evaluate the validity of using the resulting asphalt mixtures as a paving materials. Therefore, the main purpose of this study is to find the recommended gypsum rates to be used within the asphalt mixtures. As for the substitute rate for filler materials, around $40 \%$, around $75 \%$ of reproduction and hemihydrate gypsum substitutes are possible with reproduction a type of radical gypsum with the dense particle size asphalt mixture.And,it became clear in the porous asphalt mixture that a $100 \%$ substitute was possible.Also, it has been found that no heavy metal has been detected during tank leaching testing of an asphalt mixture incorporate gypsum. 